\title{
Clinical value of tumour-associated antigens
}

\author{
A. MUNRO NEVILLE
}

From the Institute of Cancer Research, Royal Cancer Hospital, Chester Beatty Research Institute, London

Since the first clear demonstration of the existence of 'specific' antigens in experimental tumours (Gross, 1943; Foley, 1953), the extensive use of syngeneic animals has resulted in the identification of tumour-associated or characteristic macromolecules ('antigens') in association with spontaneously occurring or experimentally induced tumours (Old and Boyse, 1964; Baldwin, 1970; Stonehill and Bendich, 1970). Many different types of human tumour, including colonic (Gold and Freedman, 1965a), ovarian (Levi, Keller, and Mandl, 1969), bronchial (Yachi, Matsuura, Carpenter, and Hyde, 1968), mammary (Edynak, Hirshaut, Old, and Trempe, 1971; Fossati, Canevari, Della Porta, Balzarini, and Veronesi, 1972) and bladder carcinomas (Bubeník, Perlmann, Helmstein, and Moberger, 1970), neuroblastoma (Hellström, Hellström. Pierce, and Bill, 1968), melanoma (Morton, Malmgren, Holmes, and Ketcham, 1968; Jehn, Nathanson, Schwartz, and Skumen, 1970), lymphoma (Smith, Klein, Klein, and Clifford, 1968; Klein, Clifford, Henle, Henle, Geering, and Old,1969; Buffé, Rimbaut, Lemerle, Schweisguth, and Burtin, 1970; Order, Porter, and Hellman, 1971), leukaemia (Harris et al, 1971; Halterman, Leventhal, and Mann, 1972), and sarcomas (Morton, Malmgren, Hall, and Schidlovsky, 1969; Wood and Morton, 1971) have also been shown to have tumourassociated antigens.

Of particular interest has been the finding that 'embryo or fetal associated antigens' can be present in association with human (Gold and Freedman, 1965a; Tee, Wang, and Watkins, 1965; Yachi et al, 1968; Häkkinen, and Viikari, 1969; Abelev, 1971; Mesa-Tejada, and Weiss, 1971; Trouillas, 1971) and animal tumours (Brawn, 1970; Coggin, Ambrose, and Anderson, 1970; Duff and Rapp, 1970; Baldwin, Glaves, and Vose, 1972) and that they could be released into the body fluids.

\section{Possible Clinical Applications of Tumour-associated Antigens}

The assay and identification of human tumourassociated antigens may promise new prospects in oncological medicine for the development of immunotherapeutic regimes and methods of detecting tumours together with their improved pathological classification.

One area of possible use lies in their facilitating tumour diagnosis, especially its earlier diagnosis and in improving clinical differentiation of neoplastic and non-neoplastic disorders. If successful therapy, such as surgical removal of the tumour, is associated with a return to normal levels of tumour-associated products in the body fluids, then their sequential assay during the follow-up phase may reveal rising titres which will enable recurrences to be detected earlier than by other clinical means. If therapy is instituted at that time, better survival rates may be achieved. Measurement of HCG levels in the plasma of patients with choriocarcinoma has proved to be a valuable aid in detecting residual tumour and in assessing the adequacy of therapeutic measures (Bagshawe, 1969). This line of investigation seems to be worthy of study using tumour-associated antigens as the index substances.

The detection of these antigens or their effects upon the immune system may have importance in the field of histopathology. At present, most tumours are classified histogenetically and behaviouristically, functional attributes, except for endocrine tumours, seldom being included. By outlining the tumourassociated antigens associated with a particular lesion, functional heterogeneity or homogeneity between tumours of identical or different morphology may be discerned which could have aetiological, behavioural, and prognostic significance.

In this communication, I will attempt to illustrate some of those aspects from our present knowledge of three tumour-associated antigens, namely, two oncofetal antigens, alpha-fetoprotein (AFP) (Abelev et al, 1963) and the carcinoembryonic antigen (CEA) (Gold and Freedman, 1965a and b), and the cancer basic protein (Carnegie, Caspary, and Field, 1972).

\section{Sources and Chemical Aspects}

\section{ALPHA-FETOPROTEIN}

This macromolecule was first described in the serum of neonatal mice and of adult mice bearing trans- 
plantable hepatomas by Abelev et al (1963) and in patients with hepatocellular carcinomas, by Tatarinov (1965). Subsequent studies have shown AFP to be a single chain alpha 1 -globulin (molecular weight 64000 ) containing $4 \%$ carbohydrate and which may exist in monomeric and dimeric forms (Nishi, 1970); Ruoslahti, Sepällä, Pikko, and Vuopio, 1971). Amino acid analyses have revealed that AFP and albumin are closely related proteins and that the alpha-fetoproteins extracted from fetal serum or from hepatomas are similar in amino acid composition (Nishi, 1970; Abelev, 1971; Ruoslahti et al, 1971).

Alpha-fetoprotein has been quantitated by different immunological techniques, including immunodiffusion (sensitivity of between 1 and $3 \mu \mathrm{g} / \mathrm{ml}$ serum), immunoautoradiography (sensitivity, $50 \mathrm{ng} / \mathrm{ml}$ serum) (Abelev et al, 1971) and radioimmunoassay (sensitivity, $0.25 \mathrm{ng} / \mathrm{ml}$ serum) (Ruoslahti and Seppälä, 1971). It is formed principally by the fetal liver and also by the yolk sac and gastrointestinal tract (Gitlin and Boesman, 1967; Engelhardt, Shipova, Gusev, Yazova, and Ter-Grigorova, 1969; Gitlin and Pericelli, 1970; Gitlin, 1971). In the liver, most hepatocytes are initially involved in its synthesis by the sixth week of fetal life. The serum levels reach a peak, of the order of 3 to $4 \mathrm{mg} / \mathrm{ml}$, about the thirteenth week of intrauterine life. Thereafter, the levels fall while albumin concentrations rise; these changes are paralleled by a decline in the number of AFP-forming hepatocytes which then tend to be concentrated around the central vein (Engelhardt et al, 1969). Small amounts of AFP continue to be formed by healthy adults, the detection of which requires radioimmunoassay; normal serum levels are below $10 \mathrm{ng} / \mathrm{ml}$ (Ruoslahti and Seppälä, 1971).

\section{CARCINOEMBRYONIC ANTIGEN}

In 1965, Gold and Freedman described the presence of a tumour antigen in primary adenocarcinomas of the human colon but not in autologous uninvolved colonic mucosa. It was also found in the embryonic gastrointestinal tract, liver, and pancreas during the first two trimesters of pregnancy and accordingly was called the carcinoembryonic antigen (Gold and Freedman, 1965a and b).

Detailed chemical studies of the structure of CEA are in progress and have already shown that it is a water-soluble glycoprotein with a molecular weight of approximately 200000 and that it differs in its amino acid and carbohydrate composition from blood group substances (Krupey, Gold, and Freeman, 1967, 1968; Turberville, James, Darcy, Pelly, Johns, and Neville, 1973). Carcinoembryonic antigen is associated with the glycocalyx (cell coat) of the cell membrane and is detected in particular on the luminal aspect of neoplastic cells (von Kleist and Burtin, 1969). The development of sensitive radioimmunoassays for CEA (Thomson, Krupey, Freedman, and Gold, 1969; Lo Gerfo, Krupey, and Hansen, 1971; Egan, Lautenschleger, Coligan, and Todd, 1972) has shown that small amounts of CEA exist in some normal adult digestive tract tissues (Martin and Martin, 1970; Darcy, Turberville, and James, 1973) and that nanogram levels are detectable in the body fluids of healthy adults (Hall, Laurence, Darcy, Stevens, James, Roberts, and Neville, 1972; Laurence et al, 1972; Lo Gerfo, Herter, and Bennett, 1972).

\section{CANCER BASIC PROTEIN}

Field and Caspary (1970), using a macrophage electrophoretic mobility test, reported that the lymphocytes of patients with malignant tumours were sensitized to the encephalitogenic factor (EF). This cell-mediated immune phenomenon, also observed in patients suffering from destructive neurological disorders, led them to attempt the isolation of a macromolecule closely related to encephalitogenic factor from malignant tumours. A water-soluble basic protein with a molecular weight of approximately 16000 has been identified in the plasma membrane of tumour cells (Carnegie et al, 1972). Like encephalitogenic factor, it contains a single tryptophan residue which is necessary for its antigenicity, but, using immunological and pharmacological methods, differences between encephalitogenic factor and the cancer basic protein are identifiable (Caspary and Field, 1971; Caspary, 1972; Field, Caspary, and Carnegie, 1971).

\section{Role in the Diagnosis and Differential Diagnosis of Tumours}

On presently available evidence, both AFP and CEA may have a part to play in association with particular tumours, whereas detection of lymphocyte sensitivity to the cancer basic protein is a phenomenon apparently characteristic of all malignant neoplasms. The results from two groups of workers using macrophage electrophoretic mobility test systems are shown in table $I$. The malignant tumours examined included a wide variety of epithelial neoplasms and lymphomas. Little overlap exists between the results of the control and malignant groups. Of the benign, inflammatory, or reactive conditions studied, only one example fell in the intermediate range and this patient gave a history of previous possible neurological damage (table I).

Positive results using this assay are obtained in patients with carcinomas in situ, those with advanced 


\begin{tabular}{|c|c|c|c|c|}
\hline \multirow[t]{2}{*}{ Authors } & \multirow[t]{2}{*}{ Condition } & \multicolumn{3}{|c|}{ Percentage Reduction in Macrophage Mobility } \\
\hline & & $<5 \cdot 0$ & $<12 \cdot 5$ & $>12 \cdot 5$ \\
\hline $\begin{array}{l}\text { Field and Caspary (1970) } \\
\text { Caspary (1972) }\end{array}$ & $\begin{array}{l}\text { Controls } \\
\text { Malignant tumours } \\
\text { Fibroadenoma of breast } \\
\text { Benign hypertrophy of prostate } \\
\text { Chronic bronchitis }\end{array}$ & $\begin{array}{c}79 \\
1^{2} \\
3 \\
4 \\
1\end{array}$ & $\begin{array}{c}6^{1} \\
42 \\
1^{3} \\
0 \\
0\end{array}$ & $\begin{array}{r}0 \\
154 \\
0 \\
0 \\
0\end{array}$ \\
\hline Pritchard et al (1972) & $\begin{array}{l}\text { Controls } \\
\text { Malignant tumour }\end{array}$ & $\begin{array}{r}23 \\
0\end{array}$ & $\begin{array}{l}\mathbf{0} \\
\mathbf{0}\end{array}$ & 48 \\
\hline
\end{tabular}

Table I Reduction in macrophage electrophoretic mobility in response to the encephalitogenic factor

${ }^{1}$ All were laboratory workers exposed to nervous tissue antigens. This sensitization has not been observed by Pritchard et al (1972). 'Widespread metastatic disease

'Previous history of prolapsed vertebral disc

-Patient gave history of sarcoidosis

metastatic disease as well as patients treated successfully for carcinoma up to 24 years before testing (Field and Caspary, 1970).

Seven of the 154 patients of table I grouped under the heading of 'malignant tumours' did not have neoplasms at the time of the test; one has since developed a colonic carcinoma (Caspary, 1972). This ability of the test to detect precocious lymphocyte sensitivity before the tumour becomes clinically overt has also been revealed by finding positive reactions in children born many years before their mothers apparently developed clinically overt carcinomas (Field and Caspary, 1971b).

False negative results can arise because of radiotherapy, extensive metastatic disease, lymphatic leukaemia, and in those rare individuals who fail to exhibit any type of antigenic response (Field and Caspary, 1971a, 1972), whilst false positive reactions can occur in patients with a variety of disorders including sarcoidosis, tuberculosis, intrinsic asthma, rheumatoid arthritis, DLE, exposure to the influenza viruses, and destructive neurological disease.

If the initial promise is maintained after adequate follow up in the future of patients with inflammatory and regenerative disorders, benign tumours and precancerous conditions, detection of sensitivity to this basic protein may offer real assistance to early diagnosis and differential diagnosis.

At present, AFP is detected most commonly by gel diffusion methods and the expected incidence of positive assays and their value in tumour diagnosis can be seen in table II. With this technique, raised AFP levels are remarkably specific for hepatocellular carcinoma and malignant teratomas. Other carcinomas tend only to result in positive assays once they have metastasized to the liver ( $\mathrm{O}^{\prime}$ Conor, Tatarinov, Abelev, and Uriel, 1970; Alpert, Pinn, and Isselbacher, 1971; Kozower, Fawaz, Miller, and Kaplan, 1971; Mehlman, Bulkley, and Wiernik, 1971).

Using the increased sensitivity of AFP radio-

\begin{tabular}{lll}
\hline Site & Condition & $\begin{array}{l}\text { Incidence (\%) of } \\
\text { Positive Serum Assays }\end{array}$ \\
\hline- & Normal controls & 0 \\
& Pregnancy & $1 \cdot 2$ \\
Liver & Hepatocarcinoma & 68 \\
& Cholangiocarcinoma & $1 \cdot 4$ \\
Gonad & Non-neoplastic & $0 \cdot 2^{3}$ \\
Kidney & Teratocarcinoma & 45 \\
Seminoma & 0 \\
- & Choriocarcinoma & 13 \\
& Nephroblastoma & 0 \\
& Neuroblastoma & 0 \\
& Non-hepatic primary & $0 \cdot 8^{3}$ \\
\hline
\end{tabular}

Table II Incidence of positive serum AFP assays as measured by gel diffusion techniques ${ }^{1}$

${ }^{1}$ From data reviewed by Laurence and Neville (1972)

'Almost all the positive cases were examples of viral hepatitis or cirrhosis.

All the positive examples had hepatic metastases.

immunoassay, a less specific correlation with hepatomas and teratocarcinomas is seen. Patients with cirrhosis or viral hepatitis may also have significantly raised values. Nonetheless, radioimmunoassay gives a greater number $(90-95 \%)$ of elevated AFP levels in patients with hepatocellular carcinoma. Some tumours, however, still fail to form appreciable amounts. This may be related in part to the host response. Hull, Carbone, Gitlin, O'Gara, and Kelly (1969) noted that the experimental liver tumours, induced in monkeys with nitrosodiethylamine, which possess a prominent lymphocytic infiltrate, are not associated with AFP formation. However, the round cell infiltrate disappears if and when AFP formation becomes manifest.

Whilst initial studies suggested that elevated plasma CEA levels were specific for endodermally derived carcinomas (Thomson et al, 1969), further experience has shown that raised plasma levels occur with a wide variety of non-neoplastic disorders and with neoplasms of widely differing histogenesis 


\begin{tabular}{|c|c|c|c|}
\hline \multirow[t]{2}{*}{ Site } & \multirow{2}{*}{$\begin{array}{l}\text { Condition } \\
\text { Healthy controls } \\
\text { Carcinoma of } \\
\text { Colon and rectum } \\
\text { Pancreas } \\
\text { Liver } \\
\text { Other sites }\end{array}$} & \multicolumn{2}{|c|}{ Incidence of Positive Plasma CEA Assays ( $\%)$} \\
\hline & & $\begin{array}{c}5 / 556 \\
272 / 386 \\
57 / 62 \\
12 / 18 \\
51 / 85\end{array}$ & $\begin{array}{l}(0 \cdot 9) \\
(70) \\
(92) \\
(67) \\
(60)\end{array}$ \\
\hline Gastrointestinal tract & $\begin{array}{l}\text { Polyps of } \\
\text { Colon and rectum } \\
\text { Inflammatory/Reactive } \\
\text { Ulcerative colitis and Crohn's disease } \\
\text { Diverticulitis, peptic ulceration } \\
\text { Cirrhosis and alcoholic liver disease } \\
\text { Alcoholic pancreatitis }\end{array}$ & $\begin{array}{l}10 / 77 \\
44 / 186 \\
7 / 35 \\
29 / 67 \\
17 / 32\end{array}$ & $\begin{array}{l}(13) \\
(24) \\
(20) \\
(43) \\
(53)\end{array}$ \\
\hline Breast & $\begin{array}{l}\text { Carcinoma } \\
\text { Benign tumour } \\
\text { Reactive-fibroadenosis }\end{array}$ & $\begin{array}{c}128 / 260 \\
1 / 30 \\
13 / 202\end{array}$ & $\begin{array}{r}(49) \\
(3) \\
(6)\end{array}$ \\
\hline Respiratory tract & $\begin{array}{l}\text { Carcinoma of bronchus } \\
\text { Inflammatory/Reactive } \\
\text { Pulmonary tuberculosis } \\
\text { Chronic bronchitis and emphysema }\end{array}$ & $\begin{array}{r}65 / 90 \\
8 / 21 \\
16 / 63\end{array}$ & $\begin{array}{l}\text { (72) } \\
(38) \\
(25)\end{array}$ \\
\hline
\end{tabular}

Table III Preoperative plasma CEA levels in gastrointestinal, mammary, and respiratory disorders ${ }^{1}$

${ }^{1}$ From the data of Moore et al (1971); Lo Gerfo et al (1971, 1972); Holyoke et al (1972); Laurence et al (1972); Reynoso et al (1972); and the author's further personal experience.

(Lo Gerfo et al, 1971; Moore, Kupchik, Marcon, and Zamchek, 1971; Laurence et al, 1972; MacSween, Warner, Bankhurst, and Mackay, 1972; Laurence and Neville, 1972; Reynoso et al, 1972; Zamchek, Moore, Dhar, and Kupchik, 1972). Of especial interest and potential clinical importance has been the finding of raised CEA levels in the urine of patients with urothelial carcinoma (Hall et al, 1972).

The assay of plasma CEA seems to have most clinical application in the diagnosis of carcinomas of the gastrointestinal tract, pancreas, and bronchus, approximately $70-92 \%$ of which will yield raised values (table III). It is also of value in the assessment of neuroblastoma (Reynoso et al, 1972) and possibly mammary carcinoma (table III) but has little or no part to play in the diagnosis of tumours at other sites (Laurence et al, 1972).

The component cell types of tumours or the degree of their structural differentiation do not seem to influence the level of plasma CEA (Laurence $e t$ al, 1972). This is determined more by the extent of tumour spread (table IV).

Using the assay of Egan et al (1972), it is possible to divide the plasma CEA levels into three groups, namely, normal $(<12.5 \mathrm{ng} / \mathrm{ml})$, intermediate $(12.5-$ $40 \mathrm{ng} / \mathrm{ml}$ ), and high (>40 ng/ml) (Laurence and Neville, 1972). Whilst patients with benign and malignant tumours and with inflammatory or regenerative disorders may fall into either the normal or intermediate groups, levels in excess of $40 \mathrm{ng} / \mathrm{ml}$ are nearly always diagnostic of a malignant tumour (Laurence et al, 1972). Although $30 \%$ of mammary, $41 \%$ of colonic, and $60 \%$ of bronchial carcinomas,

\begin{tabular}{llcc}
\hline Carcinoma & Stage & \multicolumn{2}{c}{$\begin{array}{c}\text { Incidence of Positive } \\
\text { Plasma Assays (\%) }\end{array}$} \\
\hline Colon and rectum & Dukes' A & $30 / 74$ & $(41)$ \\
& Dukes' B & $45 / 62$ & $(73)$ \\
& Dukes' C & $49 / 68$ & $(72)$ \\
Bronchus & Metastases & $89 / 97$ & $(92)$ \\
& Local, NO MO2 & $15 / 24$ & $(63)$ \\
Breast & Local, N+ MO' & $5 / 6$ & $(83)$ \\
& Metastases & $6 / 7$ & $(86)$ \\
Prostate & Local, NO MO2 & $27 / 88$ & $(31)$ \\
& Local, N+ MO2 & $16 / 45$ & $(36)$ \\
Bladder & Metastases & $50 / 65$ & $(77)$ \\
& Local & $5 / 28$ & $(18)$ \\
Cervix & Metastases & $7 / 13$ & $(54)$ \\
& Local & $31 / 73$ & $(42)$ \\
& Metastases & $11 / 13$ & $(85)$ \\
& Stage 0 & $1 / 7$ & $(14)$ \\
& Stage 1 & $5 / 14$ & $(36)$ \\
& Stage 2 & $5 / 9$ & $(55)$ \\
& Stage 3 & $5 / 9$ & $(55)$ \\
\hline
\end{tabular}

Table IV Plasma CEA values in relation to stage of tumour spread ${ }^{1}$

${ }^{1}$ From the data of Moore et al (1971); Lo Gerfo et al (1971 and 1972); Holyoke et al (1972); Laurence et al (1972); Reynoso et al (1972) and the author's further personal experience.

${ }^{2} \mathrm{NO}=$ no lymph node metastases; $\mathrm{MO}=$ no distant metastases; $\mathrm{N}+=$ lymph node metastases.

which are still localized at the time of surgery, yield intermediate or high values, only $8 \%, 12 \%$, and $17 \%$ respectively of such early tumours give levels in the 'cancer' diagnostic range $(>\mathbf{4 0} \mathrm{ng} / \mathrm{ml}$ ) (Laurence et $a l, 1972)$. Thus, the detection rate of even earlier lesions may be less, making plasma CEA estimation of little or no value as a screening procedure.

Since the urinary bladder is also an entodermally derived structure, it was thought that CEA might 


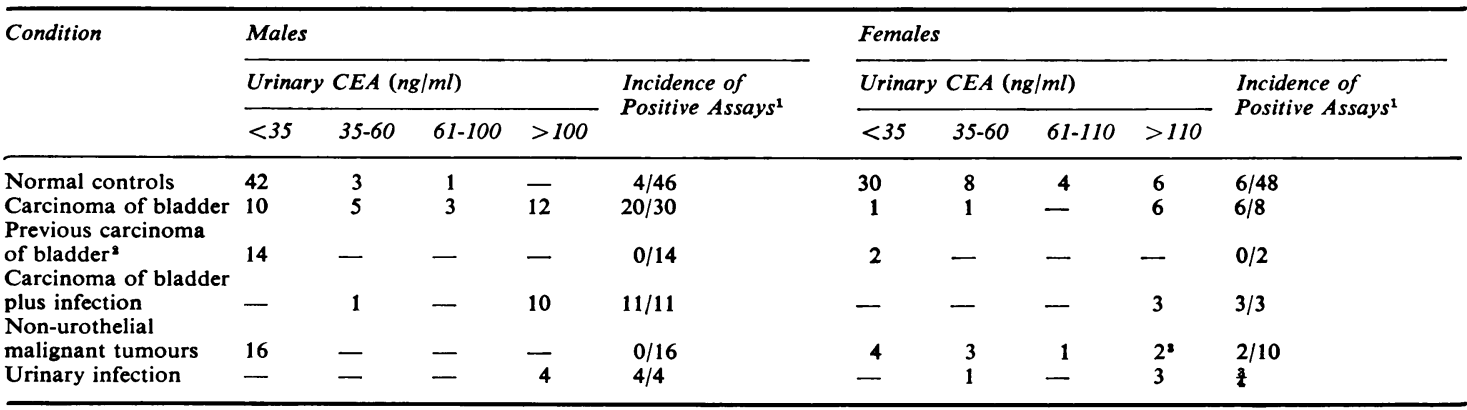

Table $\mathrm{V}$ Urinary CEA levels in health and in a variety of disorders

${ }^{1}$ Upper limit of normal in males is taken as $35 \mathrm{ng} / \mathrm{ml}$ and in females as $110 \mathrm{ng} / \mathrm{ml}$ for random urine specimens. This difference is due to vaginal and/or cervical secretion contamination of female urine specimens.

${ }^{2}$ No clinical evidence of recurrent tumour

${ }^{3}$ Infiltration of urinary tract by both tumours

occur in the urine of patients with urothelial carcinomas. Preliminary work has confirmed this hypothesis (Hall et al, 1972; table IV). Sixty-eight per cent of patients with proved urothelial carcinomas have raised urinary CEA values which return to normal when the tumour is successfully removed. Urinary CEA levels are normal in association with non-urothelial tumours, such as hypernephroma and prostatic carcinoma, even when plasma levels are raised. Only when such tumours involve the urinary tract by infiltration, do the urine levels rise. Accordingly, elevated urinary CEA levels are specific to urothelial carcinomas provided urinary infection can be excluded (Hall et al, 1972; table V).

The degree of structural tumour differentiation does not influence the level of urinary CEA (Hall et $a l, 1972)$ and high levels occur with all stages of the disease (table VI). Thus, it can be seen that well differentiated tumours in situ, which are difficult to detect by urinary exfoliative cytology, may be associated with raised levels. Consequently, urinary CEA assays could be important in the screening of highrisk population groups such as those in the rubber or dye industries.

\section{Role in Management of Patients in Follow-up Phase}

The aspect of plasma CEA estimations which is attracting most current attention is its role in the detection of residual neoplastic disease and in the development of metastases. If the plasma CEA is raised preoperatively, complete tumour removal is associated with a decline to normal levels between the second and eighteenth postoperative days; a remaining high level indicates residual disease (Dhar, Moore, Zamchek, and Kupchick, 1972; Holyoke, Reynoso, and Chu, 1972; Laurence et al, 1972). We are at present examining a large group of patients in the follow-up phase after surgical treatment for colorectal carcinoma and our experience to date, and that of Dhar et al (1972), indicate that the development of recurrent and/or metastatic disease is most often associated with a rise of CEA to pathological levels. Moreover, such a rise can occur in advance of clinically detectable tumour (fig).

Plasma CEA levels are raised in only a minority of patients with localized bladder carcinomas, but with extravesical or pelvic spread, the incidence of raised values increases (table IV). Hence, the estimation

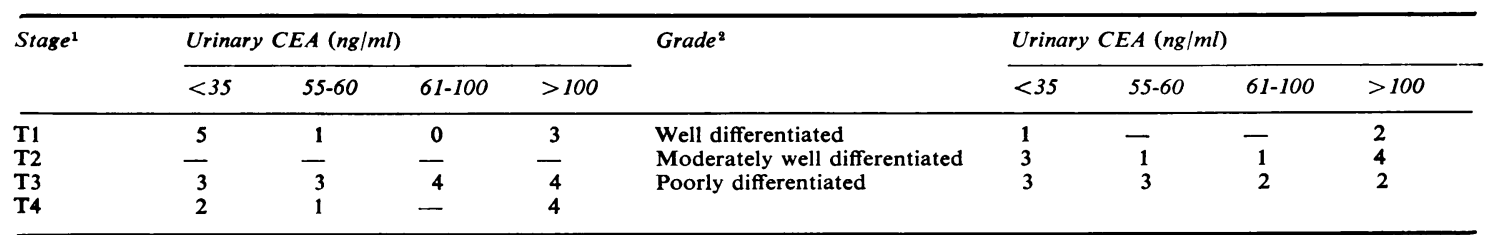

Table VI Urinary CEA levels in male patients as a function of the stage and growth of transitional cell carcinomas ${ }^{1}$ UICC classification.

'The histology of eight tumours was not available for personal review and those have been omitted 


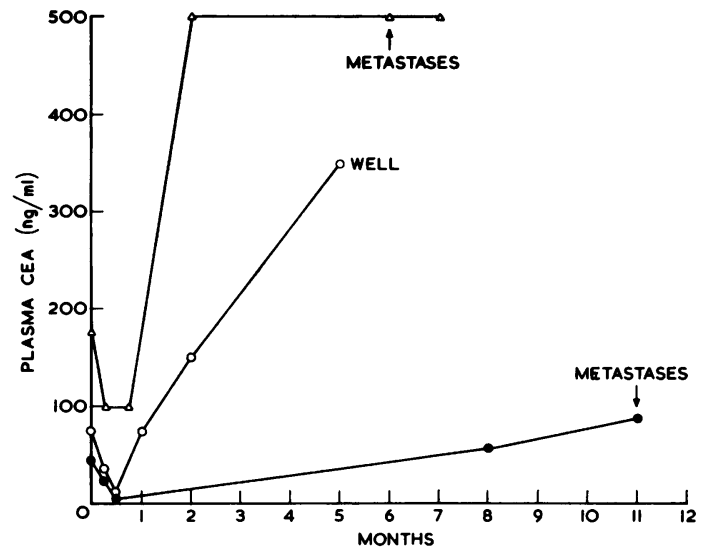

Fig Sequential changes in plasma CEA levels occurring after surgery $(0$ time $)$ and with the development of confirmed metastatic tumour in two of the three patients.

of both the urinary and plasma CEA in the followup phase after treatment may be of value in facilitating the detection of local and distant recurrences of urothelial carcinomas.

Little attention has been paid to this aspect of the clinical role of AFP assays. However, there is evidence in animals and man to suggest that the development of hepatomas may be preceded by rises in AFP serum levels and that recurrences are associated with coincident rises in AFP values to reach previous or even higher levels (Houštěk, Masopust, Kithier, and Rádl, 1968; Hull, Carbone, Gitlin, O'Gara, and Kelly, 1969; Mawas, Kohen, Lemerle, Buffé, Schweisguth, and Burtin, 1969; Khazanov, Abelev, Perova, Polenko, Ryapsova, and Shirenkova, 1971; Watabe, 1971; Braunstein, Bridson, Glass, Hull, and McIntire, 1972; McIntire, Vogel, Princler, and Patel, 1972).

\section{Role in Assessing the Effects of Therapy}

Both AFP and CEA have been employed as biochemical index substances to assess the effects of chemotherapy.

Successful therapy, including chemotherapy for hepatocarcinoma and teratocarcinoma, is associated with a decline in AFP levels which rise again with the development of recurrences (Mawas et al, 1969). Clinical improvement may be matched by falls in AFP levels but in several patients a decline in AFP values was not accompanied by any clinical response (Purves, Bersohn, and Geddes, 1970).

Holyoke and his associates (1972) have employed plasma CEA levels to monitor the effectiveness of chemotherapy. They reported that a favourable clinical response with a marked decrease in tumour size was associated with a decline of the CEA levels in plasma to normal. Relapse subsequently occurred and was preceded by a rise of CEA levels to pathological levels. These interesting observations need further study, but are of potential importance to the chemotherapist and radiotherapist.

A recent example of a hepatoblastoma secreting both HCG and AFP emphasizes the importance of trying to measure as many biochemical indices as possible for every tumour. Braunstein et al (1972) noted discordance between HCG and AFP levels in response to chemo- and/or radiotherapy which suggested that different cell lines in the same tumour may display differential responses.

\section{Role in Assessing Prognosis}

Mawas et al (1969) have commented that patients with raised AFP levels have more aggressive teratocarcinomas whilst the majority of AFP-negative malignant teratomas respond to therapy. This may represent a valuable prognostic aid in assessing tumours which may appear to be equally 'malignant' on morphological grounds. This relationship does not appear to be the case in patients with hepatomas where the levels seem to be independent of tumour size, stage, or differentiation (Purves, Macnab, and Bersohn, 1968).

It is not yet known if patients with localized tumours and high CEA levels in the plasma or urine pursue a better or worse course than those whose tumours are associated with normal CEA values. Recent experimental evidence suggests the possible importance of ascertaining this point. Kim and Carruthers (1972) examined two strains of experimental breast carcinoma which differed in their metastasizing potential. They found an inverse relationship between the presence of an antigen not necessarily CEA in the glycocalyx of the tumour cells and its concentration in serum. As the surface glycoprotein declined in amount and level in plasma rose, the metastasizing potential increased.

\section{Conclusions and Prospects}

The presence of tumour-associated macromolecules in association with human tumours is now well established. They occur within or on the cell surface and may be released into the body fluids. Many are also known to be present in fetal tissues and some possess biological activity (Laurence and Neville, 1972).

Numerous further tumour-associated antigens will almost certainly be identified in the next few years, and it is imperative that the relationship of one 
material to another and their possible role in clinical practice are examined in an integrated and meaningful manner.

None of the presently recognized tumour-associated principles are specific for malignant tumours, quantitative rather than qualitative differences exist among inflammatory disorders, benign and malignant tumours. Nonetheless, such materials have a clinical role at this time, assisting in tumour diagnosis and monitoring the effects of therapy.

It seems worthwhile in the future to attempt to measure as many as possible of the known tumourassociated principles including the 'ectopic' hormones. In this way, a battery of tests will be available which, when viewed together, may improve tumour detection and its differential diagnosis. Finally, by outlining such spectra, functional heterogeneity between tumours of identical light morphology or between cells of the same tumour may be observed which could have behaviouristic, histogenetic, and aetiological significance.

\section{References}

Abelev, G. I. (1971). Alpha-fetoprotein in ontogenesis and its association with malignant tumors. Advanc. Cancer. Res., 14, 295-358.

Abelev, G. I., Perova, S. D., Khramkova, N. I., Postnikova, Z. A., and Irlin, I. S. (1963). Production of embryonal $\alpha$-globulin by transplantable mouse hepatomas. Transplantation, 1, 174-180.

Abelev, G. I., Tsvetkov, V. S., Biryulina, T. I., Elgort, D. A., Olovnikov, A. M., Gusev, A. I., Yazova, A. K., Perova, S. D., Rubtsov, I. V., Shaborina, S. V., Kantorovich, B. A., Tur, V. M., Khazanov, A. I., and Levina, D. M. (1971). Evaluation of the use of highly sensitive methods for determination of $\alpha$-foetoprotein in the diagnosis of hepatocellular cancer and teratoblastoma. Byull. éksp. Biol. Med., 71 (4), 75-81.

Alpert, E., Pinn, V. W., and Isselbacher, K. J. (1971). Alpha-fetoprotein in a patient with gastric carcinoma metastatic to the liver. New Engl. J. Med., 285, 1058-1059.

Bagshawe, K. D. (1969). Choriocarcinoma: The Clinical Biology of the Trophoblast and its Tumours. Arnold, London.

Baldwin, R. W. (1970). Tumour specific antigens associated with chemically induced tumours. Rev. europ. Étude. clin. biol., 15, 593-598.

Baldwin, R. W., Glaves, D., and Vose, B. M. (1972). Embryonic antigen expression in chemically induced rat hepatomas and sarcomas. Int. J. Cancer, 10, 233-243.

Braunstein, G. D., Bridson, W. E., Glass, A., Hull, E. W., and McIntire, K. R. (1972). In vivo and in vitro production of human chorionic gonadotrophin and alpha-foetoprotein by a virilising hepatoblastoma. J. clin. Endocr., 35, 857-862.

Brawn, R. J. (1970). Possible association of embryonal antigen(s) with several primary 3-methylcholanthrene-induced murine sarcomas. Int. J. Cancer, 6, 245-249.

Bubenik, J., Perlmann, P., Helmstein, K., and Moberger, G. (1970). Immune response to urinary bladder tumours in man. Int. J. Cancer, 5, 39-46.

Buffe, D., Rimbaut, C., Lemerle, J., Schweisguth, O., and Burtin, P. (1970). Présence d'une ferroprotéine d'origine tissulaire. $L^{\prime} \alpha_{2} H$, dans le sérum des enfants porteurs de tumeurs. Int. J. Cancer, $5,85-87$.

Carnegie, P. R., Caspary, E. A., and Field, E. J. (1972). Identification of a tumour antigen. Biochem. J., 126, 5P-6P.

Caspary, E. A. (1972). Lymphocyte sensitization in malignant neoplasia. Proc. roy. Soc. Med., 65, 636-638.

Caspary, E. A., and Field, E. J. (1971). Specific lymphocyte sensitisation in cancer: is there a common antigen in human malignant neoplasia? Brit. med. J., 2, 613-617.

Coggin, J. H., Ambrose, K. R., and Anderson, N. G. (1970). Fetal antigen capable of inducing transplantation immunity against SV40 hamster tumor cells. J. Immunol., 105, 524-526.

Darcy, D., Turberville, C., and James, R. (1973). Immunological study of carcino-embryonic antigen (CEA) and a related glycoprotein. Brit. J. Cancer, 28, 147-160.

Dhar, P., Moore, T., Zamcheck, N., and Kupchik, H. Z. (1972). Carcinoembryonic antigen (CEA) in colonic cancer. J. Amer. med. Ass., 221, 31-35.

Duff, R., and Rapp, F. (1970). Reaction of serum from pregnant hamsters with surface of cells transformed by SV40. J. Immunol., 105, 521-523.

Edynak, E. M., Hirshaut, Y., Old, L. J., and Trempe, G. L. (1971). Antigens of human breast cancer. Proc. Amer. Ass. Cancer Res., 12, 75A.

Egan, M. L., Lautenschleger, J. T., Coligan, J. E., and Todd, C. W. (1972). Radioimmune assay of carcinoembryonic antigen. Immunochemistry, 9, 289-299.

Engelhardt, N. V., Shipova, L. Y., Gusev, A. I., Yazova, A. K., and Ter-Grigorova, E. N. (1969). Observations on the $x_{\text {rglobulin }}$ in sections of human embryo liver and the liver of newborn mice by the fluorescent antibody method. Byull. éksp. Biol. Med., 68 (12), 62-64.

Field, E. J., and Caspary, E. A. (1970). Lymphocyte sensitisation : an in vitro test for cancer? Lancet, 2, 1337-1341.

Field, E. J., and Caspary, E. A. (1971a). Lymphocyte sensitisation in cancer. Lancet, 1, 189-190.

Field, E. J., and Caspary, E. A. (1971b). Is maternal lymphocyte sensitisation passed to the child? Lancet, 2, 337-342.

Field, E. J., and Caspary, E. A. (1972). Lymphocyte sensitization in advanced malignant disease: a study of serum lymphocyte depressive factor. Brit. $J$. Cancer, 26, 164-173.

Field, E. J., Caspary, E. A., and Carnegie, P. R. (1971). Lymphocyte sensitisation to basic protein of brain in malignant neoplasia: experiments with serotonin and related compounds. Nature (Lond.), 233, 284-286.

Foley, E. J. (1953). Antigenic properties of methylcholanthreneinduced tumors in mice of the strain of origin. Cancer Res., 13, 835-837.

Fossati, G., Canevari, S., Della Porta, G., Balzarini, G. P., and Veronesi, U. (1972). Cellular immunity to human breast carcinoma. Int. J. Cancer, 10, 391-396.

Gitlin, D. (1971). Sites of alpha-fetoprotein synthesis. New Engl. J. Med., 285, 1436-1437.

Gitlin, D., and Boesman, M. (1967). Sites of serum alpha-fetoprotein synthesis in the human and in the rat. J. clin. Invest., 46, 10101016.

Gitlin, D., and Pericelli, A. (1970). Synthesis of serum albumin, prealbumin, $\alpha$-foetoprotein, $x_{1}$-antitrypsin and transferrin by the human yolk sac. Nature (Lond.), 228, 995-997.

Gold, P., and Freedman, S. O. (1965a). Demonstration of tumorspecific antigens in human colonic carcinomata by immunological tolerance and absorption techniques. J. exp. Med., 121, 439-462.

Gold, P., and Freedman, S. O. (1965b). Specific carcinoembryonic antigens of the human digestive system. J. exp. Med., 122, $467-481$.

Gross, L. (1943). Intradermal immunization of C3H mice against a sarcoma that originated in an animal of the same line. Cancer Res., 3, 326-333.

Hãkkinen, I., and Viikari, S. (1969). Occurrence of fetal sulphoglycoprotein antigen in the gastric juice of patients with gastric diseases. Ann. Surg., 169, 277-281.

Hall, R. R. Laurence, D. J. R., Darcy, D., Stevens, U., James, R., Roberts, S., and Neville, A. M. (1972). Carcinoembryonic antigen in the urine of patients with urothelial carcinoma. Brit. med. J., 3, 609-611.

Halterman, R. H., Leventhal, B. G., and Mann, D. L. (1972). An acute-leukemia antigen: correlation with clinical status. New Engl. J. Med., 287, 1272-1274.

Harris, R., Viza, D., Todd, R., Phillips, J., Sugar, R., Jennison, R. F., Marriott, G., and Gleeson, M. H. (1971). Detection of human leukaemia associated antigens in leukaemic serum and normal embryos. Nature (Lond.), 233, 556-557.

Hellström, I., Hellström, K. E. Pierce, G. E., and Bill, A. H. (1968). Demonstration of cell-bound and humoral immunity against neuroblastoma cells. Proc. nat. Acad. Sci. (Wash.), 60, 12311238.

Holyoke, D., Reynoso, G., and Chu, T. M. (1972). Carcinoembryonic antigen (CEA) in patients with carcinoma of the digestive tract. Ann. Surg., 176, 559-564.

Houštěk, J., Masopust, J., Kithier, K., and Rádl, J. (1968). Hepatocellular carcinoma in association with a specific fetal alpha-1globulin fetoprotein. J. Pediat., 72, 186-193. 
Hull, E. W., Carbone, P. P., Gitlin, D., O'Gara, R. W., and Kelly, M. G. (1969). $\alpha$-Fetoprotein in monkeys with hepatoma. J. nat. Cancer Inst., 42, 1035-1044.

Jehn, U. W., Nathanson, L., Schwartz, R. S., and Skumen, M. (1970). In vitro lymphocyte stimulation by a soluble antigen from malignant melanoma. New Engl. J. Med., 283, 329-333.

Khazanov, A. J., Abelev, G. I., Perova, S. D., Polenko, V. K., Ryapsova, U. K., and Shirenkova, O. (1971). Quoted by Abelev, G. I. (1971).

Kim, U., and Carruthers, C. (1972). Relationship between glycocalyx dissociability, surface antigen solubility, immunogenicity and metastasizing capacity of mammary carcinomas. (Abstr.) Proc. Amer. Ass. Cancer Res., 13, 69.

Klavins, J. V., Mesa-Tejada, R., and Weiss, M. (1971). Human carcinoma antigens cross-reacting with anti-embryonic antibodies. Nature [new Biol.], 234, 153-154.

Klein, G., Clifford, P., Henle, G., Henle, W., Geering, G., and Old, L. J. (1969). EBV-associated serological patterns in a Burkitt lymphoma patient during regression and recurrence. Int.J. Cancer, 4, 416-421.

von Kleist, S., and Burtin, P. (1969). Isolation of a fetal antigen from human colonic tumors. Cancer Res., 29, 1961-1964.

Kozower, M., Fawaz, K. A., Miller, H. M., and Kaplan, M. M. (1971). Positive alpha-fetoglobulin in a case of gastric carcinoma. New Engl. J. Med., 285, 1059-1060.

Krupey, J., Gold, P., and Freedman, S. O. (1967). Purification and characterisation of carcinoembryonic antigens of the human digestive system. Nature (Lond.), 215, 67-68.

Krupey, J., Gold, P., and Freedman, S. O. (1968). Physicochemical studies of the carcinoembryonic antigens of the human digestive system. J. exp. Med., 128, 387-398.

Laurence, D. J. R., and Neville, A. M. (1972). Foetal antigens and their role in the diagnosis and clinical management of human neoplasms: a review. Brit. J. Cancer, 26, 335-355.

Laurence, D. J. R., Stevens, U., Bettelheim, R., Darcy, D., Leese, C., Turberville, C., Alexander, P., Johns, E. W., and Neville, A. M. (1972). Role of plasma carcinoembryonic antigen in the diagnosis of gastrointestinal, mammary and bronchial carcinoma. Brit. med. J., 3, 605-609.

Levi, M. M., Keller, S., and Mandl, I. (1969). Antigenicity of a papillary serous cystadenocarcinoma tissue homogenate and its fractions. Amer. J. Obstet. Gynec., 105, 856-861.

Lo Gerfo, P., Herter, F. P., and Bennett, S. J. (1972). Absence of circulating antibodies to carcinoembryonic antigen in patients with gastrointestinal malignancies. Int. J. Cancer, 9, 344-348.

Lo Gerfo, P., Krupey, J., and Hansen, H. J. (1971). Demonstration of an antigen common to several varieties of neoplasia. New Eng . J. Med., 285, 138-141.

McIntire, K. R., Vogel, C. L., Princler, G. L., and Patel, I. R. (1972). Serum $\alpha$-fetoprotein as a biochemical marker for hepatocellular carcinoma. Cancer Res., 32, 1941-1946.

MacSween, J. M., Warner, N. L., Bankhurst, A. D., and Mackay, I. R. (1972). Carcinoembryonic antigen in whole serum. Brit. J. Cancer, 26, 356-360.

Martin, F., and Martin, M. S. (1970). Demonstration of antigens related to colonic cancer in the human digestive system. Int. J. Cancer, 6, 352-360.

Mawas, C., Kohen, M., Lemerle, J., Buffe, D., Schweisguth, O., and Burtin, P. (1969). Serum $\alpha_{1}$ foeto-protein (fetuin) in children with malignant ovarian or testicular teratomas: preliminary results. Int. J. Cancer, 4, 76-79.

Mehlman, D. J., Bulkley, B. H., and Wiernik, P. H. (1971). Serum alpha 1 -fetoglobulin with gastric and prostatic carcinomas. New Engl. J. Med., 285, 1060-1061.

Moore, T. L., Kupchik, H. Z., Marcon, N., and Zamcheck, N. (1971). Carcinoembryonic antigen assay in cancer of the colon and pancreas and other digestive tract disorders. Amer. J. dig. Dis., 16, 1-7.

Morton, D. L., Malmgren, R. A., Hall, W. T., and Schidlovsky, G. (1969). Immunologic and virus studies with human sarcomas. Surgery, 66, 152-161.

Morton, D. L., Malmgren, R. A., Holmes, E. C., and Ketcham, A. S. (1968). Demonstration of antibodies against human malignant melanoma by immunofluorescence. Surgery, 64, 233-240.
Nishi, S. (1970). Isolation and characterisation of a human fetal $\alpha$-globulin from the sera of fetuses and a heptoma patient. Cancer Res., 30, 2507-2513.

O'Conor, G. T., Tatarinov, Y. S., Abelev, G. I., and Uriel, J. (1970). A collaborative study for the evaluation of a serologic test for primary liver cancer. Cancer (Philad.), 25, 1091-1098.

Old, L. J., and Boyse, E. A. (1964). Immunology of experimental tumors. Ann. Rev. Med., 15, 167-186.

Order, S. E., Porter, M., and Hellmann, S. (1971). Hodgkin's disease: evidence for a tumor-associated antigen. New Engl. J. Med., 285, 471-474.

Pritchard, J. A. V., Moore, J. L., Sutherland, W. H., and Joslin, C. A. F. (1972). Macrophage electrophoretic mobility (M.E.M. test for malignant disease). Lancet, 2, 627-629.

Purves, L. R., Bersohn, I., and Geddes, E. W. (1970). Serum alphafeto-protein and primary cancer of the liver in man. Cancer (Philad.), 25, 1261-1270.

Purves, L. R., Macnab, M., and Bersohn, I. (1968). Serum alphafetoprotein. I. Immunodiffusion and immuno-assay results in cases of primary cancer of the liver. S. Afr. J. Med., 42, 11381141.

Reynoso, G., Chu, T. M., Holyoke, D., Cohen, E., Nemoto, T., Wang, J-J., Chuang, J., Guinan, P., and Murphy, G. P. (1972). Carcinoembryonic antigen in patients with different cancers. J. Amer. med. Ass., 220, 361-365.

Ruoslahti, E., and Seppälä, M. (1971). Studies of carcino-fetal proteins. III. Development of a radioimmunoassay for $\alpha$-fetoprotein: demonstration of $\alpha$-fetoprotein in serum of healthy human adults. Int. J. Cancer, 8, 374-383.

Ruoslahti, E., Seppälä, M., Pihko, H., and Vuopio, P. (1971). Studies of carcino-fetal proteins. II. Biochemical comparison of $\alpha-$ fetoprotein from human fetuses and patients with hepatocellular cancer. Int. J. Cancer, 8, 283-288.

Smith, R. T., Klein, G., Klein, E., and Clifford, P. (1968). Studies of the membrane phenomenon in cultured and biopsy cell lines from the Burkitt lymphoma. In Advances in Transplantation; Proceedings of the First International Congress of the Transplantation Society, 1967, edited by J. Dausset, J. Hamberger, and G. Mathe, pp. 483-493. Williams and Wilkins, Baltimore.

Stonehill, E. H., and Bendich, A. (1970). Retrogenetic expression: the reappearance of embryonal antigens in cancer cells. Nature (Lond.), 228, 370-372.

Tatarinov, Y. S. (1965). The content of an embryospecific $\alpha$-globulin in the serum of human embryos, of new-born babies and of adults in cases of primary carcinoma of the liver. Vop. med. Khim., 11 (2), 20-24.

Tee, D. E. H., Wang, M., and Watkins, J. (1965). Antigenic properties of human tumours; 'tumour-specific' antigens. Europ. $J$. Cancer, 1, 315-317.

Thomson, D. M. P., Krupey, J., Freedman, S. O., and Gold, P. (1969). The radioimmunoassay of circulating carcinoembryonic antigen of the human digestive system. Proc. nat. Acad. Sci. (Wash.), 64, 161-167.

Trouillas, P. (1971). Carcino-fetal antigen in glial tumours. Lancet, 2, 552.

Turberville, C., Darcy, D., Lawrence, D. J. R., Johns, E. W., and Neville, A. M. (1973). Studies on carcinoembryonic antigen (CEA) and a related glycoprotein. I. Immunological aspects. Immunochemistry, 10, 841-843.

Watabe, H. (1971). Early appearance of embryonic $\alpha$-globulin in rat serum during carcinogenesis with 4-dimethylaminoazobenzene. Cancer Res., 31, 1192-1194.

Wood, W. C., and Morton, D. L. (1971). Host immune response to a common cell surface antigen in human sarcomas. New Engl.J. Med., 284, 569-572.

Yachi, A., Matsuura, Y., Carpenter, C. M., and Hyde, L. (1968). Immunochemical studies on human lung cancer antigens soluble in $50 \%$ saturated ammonium sulfate. $J$. nat. Cancer Inst., 40, 663-682.

Zamcheck, N., Moore, T. L., Dhar, P., and Kupchik, H. (1972). Immunologic diagnosis and prognosis of human digestive tract cancer: carcinoembryonic antigen. New Engl. J. Med., 286, 83-86. 